\title{
EXPLORING SKILLS NEEDED FOR DISRUPTIVE DIGITAL BUSINESS
}

\author{
Dewi Wahyu Handayani ${ }^{1}$, Jann Hidajat Tjakraatmadja ${ }^{2}$, and Achmad Ghazali ${ }^{3}$ \\ ${ }^{1}$ Doctoral Program School of Business and Management, Institute Technology Bandung \\ ${ }^{2,3}$ School of Business and Management, Institute Technology Bandung
}

\begin{abstract}
Research Purpose - In today's disruptive digital business era, many new business models, such as digital start-ups, have emerged, and this phenomenon needs workers with particular skills. The aims of this preliminary empirical research paper are to explore and identify the skills needed for disruptive digital business in the Indonesian context, particularly in the Jakarta region.

Design/methodology/approach - This qualitative study conducted semi-structured interviews with ten respondents from various types of Indonesian start-ups, such as unicorn start-up, financial technology and education technology, that have been in operation four to 12 years. The interviews were based on five core questions with the purpose of exploring respondents' experience regarding skills needed and challenges faced at work in disruptive digital business. Observation was conducted at the Education Technology start-up office located in Jakarta with an aim to investigate workplace environment, and triangulation was used to validate the interviews' results.
\end{abstract}

Findings - The results show that (1) innovativeness, (2) leadership skills, (3) social interaction, (4) initiative mindsets, (5) self-disruption, (6) critical thinking, (7) management, and (8) analytical thinking are eight pivotal skills identified for managing disruptive digital business.

Vol. 28, No. 3 December 2020

(C) Centre for Indonesian Accounting and Management Research Postgraduate Program, Brawijaya University 
Practical implications - Innovativeness, leadership and social interaction are the top three skills that are essential for actors in Indonesian digital start-ups to have competitive advantages in this disruptive digital business era.

Original/value - This paper explores skills needed for the disruptive digital era in an Indonesian context.

Keywords - skills concepts, disruptive, digital business

Paper type - Research paper

\section{INTRODUCTION}

Education and skill of the workforce are among the four pillars of a knowledge-based economy (World Bank Institute, 2008). The term "skill" is used to refer to individual abilities, a concept has been widely studied before by Lawler (1992), Brian and Barry (1998), Kun and Weinberger (2005), Ngang and Chan (2015) and Laar et al. (2020). Skills are considered as resources - individual and organizational traits - that will enable organizations to have competitive advantage and productivity (Sousa and Rocha, 2017). Skills are embedded in every employee and become an organization's intangible resources. Every organization is obliged to continually sharpen and improve its employee skills because advanced employee skills show how an organization also learns and grows together, which is ultimately useful for achieving company goals. Because the business market has changed, skills development has become essential as a strategic management tool to cope with the turbulent and uncertain business environment (Nyhan, 1998).

In today's volatile and uncertain global competition (Bennet and Lemoine, 2012), a new, disruptive business model has arrived (King and Badham, 2018). 
Digitalisation, internet connectivity, global competition, and business innovation are factors that make disruptive digital businesses emerge. Industries such as retail, transportation, education, banking and financial services, logistics, media and travel agents are changing due to digital technology innovation. Matahari department store, "Express" taxi and "Kosti" taxi, "ojek pangkalan" (Indonesian public motorcycle transportation), and MetroMini (Indonesian minibus public transportation) are examples of Indonesian businesses that used to exist, but unfortunately are now closed or reducing their stores or units due to digital technology disruption in the existing market. On the other hand, the digital technology era offers an opportunity for people to create a new business model, such as start-ups. A start-up is a human institution designed to create a new product or service under conditions of extreme uncertainty (Ries, 2011). Start-ups in the digital technology era have extraordinary traits because it is predicted they will eliminate technology giants (Gartner, 2019). In Indonesia, there were 992 start-ups in 2018 (MIKTI, 2018), and in 2019, the Ministry of Communication and Information Technology, began a programme called the "1,000 Digital Start-up Movement" to give birth to new start-ups (Viska, 2019). This programme aims to evoke a new industrial movement that will make Indonesia the world's biggest business digital power, in Southeast Asia and the world (Rudiantara, 2019).

In a disruptive digital era, businesses such as digital start-ups require a workforce that has specific skills that can bring value to the company in the form of innovation. In this paper, we refer to the individual capabilities needed to work in digital start-ups as a new business model in the disruptive era. Unlike in the market customisation era (Nyhan, 1998), in the current digital era, business is more directed towards business trends in the 
form of the sharing economy. The sharing economy, also known as collaborative consumption (Hamari et al., 2015), is described as business activities of firms that connect other interdependent business actors as "sellers" and "buyers" in services contexts such as transportation (Cusumano, 2015). By looking at this trend, what are the most appropriate skills in disruptive digital business? The purpose of this research is to explore and identify what skills are needed for disruptive digital business in the Indonesian context, particularly in the Jakarta region. The research question is proposed to summarise the phenomenon described above.

RQ: What skills are needed to manage a disruptive digital business in the Indonesian context?

Furthermore, this paper is intended to complement the previous research of skills required at work, particularly what skills are needed in a disruptive digital business in the Indonesian context.

\section{LITERATURE REVIEW}

\section{Skills Concept}

Skills are considered as a resource of individual and organizational nature that would allow competitiveness and productivity advantages to the company (Sousa and Rocha, 2017). Historically, the word skills has been used to refer to individual characteristics. Skills development prevails as a research issue that is very important for the competitiveness of the market and is perceived as a strategic management tool to cope with the current business environment. There are management skills concepts for different levels of management as follows (Huusko, 2006): 
(1) Technical skills, which consist of knowledge about methods, system, rules and structure;

(2) Human relations, which consist of knowledge about human behaviour and group processes; and

(3) Conceptual skills, which consist of analytical ability, inductive and deductive reasoning.

Meanwhile, Colombo et al. (2019) identified some skills for the labour market of the future are:

(1) Hard skills, which consist of information brokerage skills, basic ICT skills, management ICT skills; and

(2) Soft skills, which consist of thinking skills, social interaction, application of knowledge, attitudes and values.

In this research, we focus on exploring both the hard and soft skills needed in Indonesian digital start-ups. The term "soft skills" refers to personal attributes that are important to enhance an individual's interaction (Hendarman and Tjakraatmadja, 2012), and "hard skills" refer to an individual's ability to perform on the job and frequently involve activities of knowledge acquisition (Rainsbury et al., 2002). Thus, in the context of Indonesian digital start-ups in the disruptive era, we see both hard and skills are essential.

\section{Disruptive}

This section of the literature review shows the exploration of disruptive terms from previous research. Schuelke-Leech (2017) stated that disruptive technologies are closely 
related to innovation. The terms "disruptive technology" or "disruptive innovation" started with Schumpeter (1934), Tarde (1969) and Rogers (2003), and then Christensen (1997) published The Innovator's Dilemma. Organizations and business owners today must realise that disruptive technologies will create the winners and the losers in addition to many changes. Disruptive technologies are identified with several conditions:

(1) Emerging IT, such as the boom of the internet, mobile technologies, artificial intelligence, big data, and robotics, are potentially causing changes in organizations and society (Sousa and Rocha, 2017; Vasconcelos et al., 2017);

(2) When an organization focuses on the Internet of Things, then it will have the possibility of sharing equipment, network system, devices, and information using an internet communication protocol (Guinard et al., 2011);

(3) Cloud technology is a model that allows access to an omnipresent network upon request from a shared pool such as servers and storage (Chard et al., 2010);

(4) Big data, which is a phenomenon that has potential value for the development of new management techniques and analysis (Sousa and Rocha, 2017); and

(5) Artificial intelligence, a computer system development that has the ability to do tasks that require human intelligence and has numerous applications in industry (Thompson and Miller, 2018).

In this paper, we focus on how the disruptive era has changed the nature of business and work. Therefore, we intended to explore what specific skills are needed to manage a business in this disruptive era. 


\section{Digital Business}

The concept of business model is helpful to gain a deeper understanding of the business logic of a company by explaining how value is created, delivered and captured (Remane et al., 2017). The digital business model is a business model categorised as such due to the digital technologies that trigger fundamental changes in these value dimensions (Scallmo, et al., 2017). Digital business has three unique characteristics:

(1) Digital products and services can be reproduced, becoming exponentially more valuable as more users join i.e., Instagram, Facebook (Varian,1999);

(2) In digital business, value is determined when already in use by customers i.e., online learning, mobile payment (Vargo and Lusch, 2008); and

(3) Digital business models rely on a digital platform to benefit from the ecosystem they build (Lansiti and Levien, 2004).

In this research, we use digital start-up as representative of digital business. Start-up refers to an organization formed to search for a repeatable and scalable business model (Blank, 2010), whereas digital start-up is a business model that uses a digital platform to do all its business operation.

\section{RESEARCH METHODOLOGY/APPROACH}

To answer the research question, we use a qualitative approach with semi-structured interviews with ten respondents equipped with an ethics statement and consent form. This qualitative research involves working with rich data, such as journals, articles, regional and international news, in-depth interviews, and observation, which allows researchers to construct a new understanding of the underlying social reality and phenomenon (Sale et 
al., 2002). According to Newing (2011), the strength of qualitative interviews is in providing background information and context, generating ideas and providing in-depth information on each participant's views, perspectives and motivations. We conducted qualitative semi-structured interviews and observation with aim to better understand and explore what kind of skills are needed by actors who work at digital start-ups in Indonesia. Figure 1. shows the exploratory research design of this study.

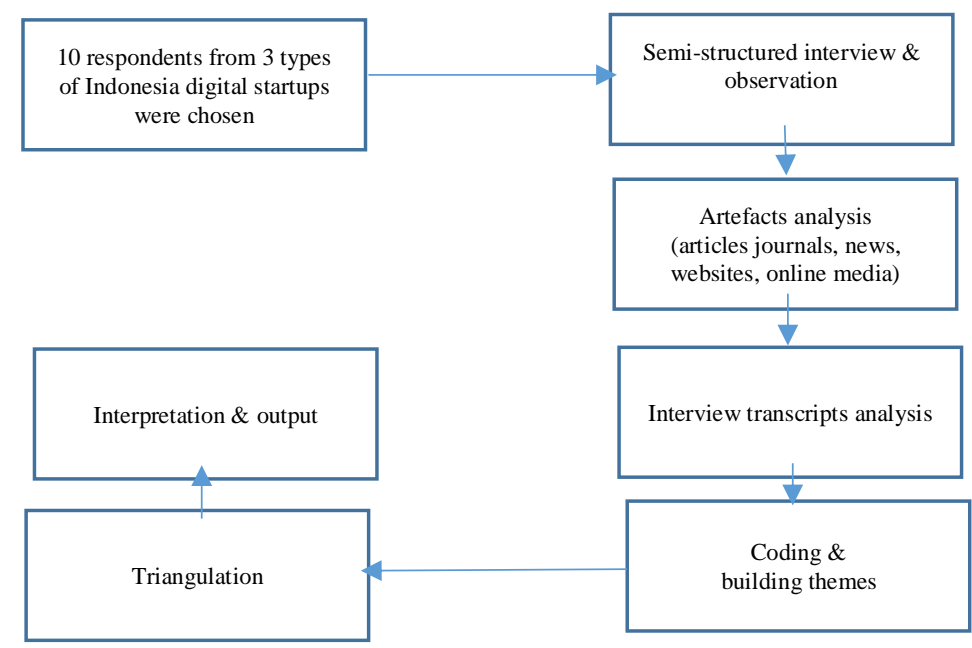

Figure 1. The Exploratory Research Design of Skills Needed for Disruptive Digital

\section{Business}

From Figure 1, we selected respondents from three types of digital start-ups, which are digital marketplace (Indonesian unicorn's start-up), education technology and financial technology, have been operating between four and 12 years, and all are located in Jakarta. We chose digital start-ups in the Jakarta region as research objects because this region has the largest number of start-ups in Indonesia (MIKTI, 2018). Table 1 shows the list of the ten respondents and their start-up's profiles. 
Table 1. Respondents and Startups Profiles

\begin{tabular}{|c|c|c|c|c|}
\hline \multirow[b]{2}{*}{ No } & \multicolumn{4}{|c|}{ Respondents } \\
\hline & Job Position & Startup & $\begin{array}{c}\text { Company's } \\
\text { Age }\end{array}$ & Total \\
\hline 1 & Chief Executive Officer & Digital Marketplace & 9 years & 1 \\
\hline 2 & President & Education Technology & 12 years & 1 \\
\hline 3 & Vice President & Education Technology & 12 years & 1 \\
\hline 4 & Senior Manager of Product Category & Digital Marketplace & 10 years & 1 \\
\hline 5 & $\begin{array}{l}\text { Virtual Product Development } \\
\text { Manager }\end{array}$ & Digital Marketplace & 9 years & 1 \\
\hline 6 & Tutor Manager & Education Technology & 12 years & 1 \\
\hline 7 & Social Media Manager & Education Technology & 12 years & 1 \\
\hline 8 & Content Analyst & Education Technology & 5 years & 1 \\
\hline 9 & HR Generalist & Financial Technology & 4 years & 1 \\
\hline 10 & Technical Talent Acquisition & Financial Technology & 4 years & 1 \\
\hline
\end{tabular}

Source: primary data, the authors (2019)

Table 1 shows that the ten respondents chosen to be interviewed included Clevel, senior managers, managers and staff. We chose to interview respondents from different managerial levels because skills at different levels of management are related to the differing role requirements at each managerial level (Huusko, 2006). Semi-structured interviews were conducted by face to face, email and telephone interviews, with a duration 45 to 50 minutes. The five core interview questions are about the respondent's experience about skills used to support his/her daily work and performance, challenges faced working in digital start-ups and innovation or idea creation (please see Appendix 1 For a more detailed list of interview questions). Notebook and voice recording tools were used during the interview process, while the ethics statement and consent form was also deployed to the respective respondents to establish the ethics code and avoid conflicts of interest. To be included in this study, the respondent should have a minimum one year 
working experience in a start-up. Respondents' ages ranged from 24 to 37 years old, and they had a variety of educational backgrounds from Bachelor's to Master's degrees.

We aimed to explore and gain insight from their experiences and perspectives regarding what hard skills and, particularly, soft skills are needed at work in digital startups as a form of disruptive digital business. For these reasons, we chose respondents that have work experiences at digital start-ups from one year two months to 12 years. Furthermore, we intended to explore how respondents deal with disruptive digital business since their first year and what skills they used to manage that condition. Meanwhile, the observation was conducted at an education technology start-up office located in Jakarta on April $18^{\text {th, }}$ 2019, with the aim of investigating the work and social environment at the digital start-up.

Saunders et al. (2016) state that a validity test is an essential for appropriateness of the measures researchers use, the accuracy of the analysis of the results, and generalizability of the findings. In order to validate the accuracy of the interview results, we used triangulation. In triangulation, "The researcher makes use of multiple and different sources, methods, investigators, and theories to provide corroborating evidence" (Creswell, 2013 p. 251).

Once we finished the semi-structured interviews, we performed triangulation by discussing the results of the in-depth interview transcripts and crosschecked with the president of the educational technology start-up as his superior to gain insight. The president of the education technology start-up also ensured quality and helped with checking between transcripts and implementation. Triangulation was also conducted by insight gained from the CEO of the digital marketplace (Indonesian unicorn) when he 
shared knowledge and a question and answer session at a Knowledge Café event at SBMITB on Saturday, July 27th, 2019. The analysis and interpretation of interview results will be discussed in the findings and conclusion session.

\section{FINDINGS}

This study aimed to explore and identify what skills are needed for disruptive digital business in the Indonesian context, particularly in the Jakarta region. Ten respondents answered and shared their experiences regarding skills that are used to support daily work and job performance along with challenges they face working at digital start-ups in this disruptive era. We analysed all the verbatim responses and had several codings. Eight themes emerged: (1) critical thinking, (2) self-disruption, (3) leadership skills, (4) analytical thinking, (5) management skills, (6) innovativeness, (7) social interaction skills, and (8) initiative mindsets.

\section{(1) Critical thinking.}

Among the ten respondents, critical thinking skill was mentioned by Tutor Manager (having 18 subordinates with three years' work experience at the education technology start-up) as one of the essential skills required in the digital business of education.

"For my position as Tutor Manager, I really need critical thinking skills, analytical thinking, scientific reasoning, and also I need managing people skills because I must manage and organize many tutors as my subordinates." - SY, Tutor Manager. May 2019

In an education technology start-up, having strong critical thinking is essential because the ability to think rationally is the core of the digital education business.

(2) Self-disruption. 
This skill is unique and was stated by the founder of the Indonesian unicorn startup. Self-disruption refers to skills possessed by open-minded employees, who do not like the comfort zone and are accustomed to looking for new ideas to give more value to the work they do.

"I always encourage my team to do self-disruption. It means they should have a mindset that there is something to be disrupted or change to be better and not live in a comfort zone." - AZ, CEO, July 2019

Two of the ten respondents acknowledged that self-disruption is one of the critical soft skills for managing a disruptive digital business in order to obtain company competitiveness.

"What I like the most about working at a digital marketplace is everyone has passion to generate an idea and make positive change." - LT, Product Category Senior Manager, March 2019

A similar experience about self-disruptive ability was shared by the senior managerial at another digital marketplace (Indonesian unicorn). Always creating a fresh idea and delivering positive change in their everyday work seems to be a pivotal soft skill for a digital start-up in the unicorn category.

(3) Leadership skills

Four of the ten respondents shared how important leadership skills are in digital start-ups. A senior manager at the digital marketplace (Indonesian unicorn) who has six subordinates admitted that leadership skills are important to managing a team.

"I think it's essential that every employee has leadership skills." - LT, Product Category Senior Manager, March 2019

Moreover, leadership skills were also acknowledged by three staff members at the education technology and financial technology start-ups as predominant soft skills they must have.

Vol. 28, No. 3 December 2020

(C) Centre for Indonesian Accounting and Management Research Postgraduate Program, Brawijaya University 
"Besides being up to date about what happening technology, I need to have leadership skills for my job because I must handle junior employees and give them direction during onboard." - AW, Technical Talent Acquisition, August 2019

"As content analyst, I need to lead my team to fulfil the project's goal"- EM, Content Analyst, April 2019

"Since I joined this company, I feel that I must have a leadership spirit, even though at the moment I do not have subordinates. However, I need leadership skills to manage myself..." - OL, HR Generalist, August 2019

One of digital start-up characteristics is remote working, and relevant with Blank (2010), who stated that a start-up is a temporary organization that tries to find a business model that is repeatable and scalable. Thus, in this phase, all of the digital start-up's employees should have the ability to manage and lead themselves to achieve the company’s goal.

(4) Analytical thinking

The ability to examine anything that relates to daily work and problems in detailed systematic information was also mentioned by the respondent at an education technology start-up who usually deals with the project and meets what the client needs.

"I think in my job position, I need analytical thinking and time management to fulfil my target..." - EM, Content Analyst, April 2019

\section{(5) Management skills}

Two of the ten respondents mentioned that management skills are needed in digital start-ups to manage their work and achieve the company's goal.

"...as vice president of engineering, I really need management and leadership skills..." - IPH, Vice President of Engineering, May 2019

"At Education Technology start-up, managing resources tutoring is needed..." - SY, Tutor Manager, June 2019

Vol. 28, No. 3 December 2020 (C) Centre for Indonesian Accounting and Management Research Postgraduate Program, Brawijaya University 
The ability to the do plan-do-check-act cycle is also important and needed in digital start-ups. In particular, this hard skill becomes a pre-requisite for managers and Clevels to manage their teams.

(6) Innovativeness

Six of the ten respondents acknowledged that innovativeness is a vital skill needed by a digital start-up in any stage. A senior manager at a digital marketplace (Indonesian unicorn) stated:

"Yes, we do innovation. As an innovation process, we do research... [ ], developed new features..." - LT, Product Category Senior Manager, March 2019

We analyse that digital start-ups as a new business model in the disruptive era must adopt the new technology and platform-based business model. Therefore, they must do innovation, and this is mostly radical innovation at all organizational levels, from top to down.

"...Yes, I think every employee must have innovativeness. This mindset is not only limited to engineering employees, but it is for all employees. " - IPH, Vice President of Engineering, May 2019

"Innovativeness became a significant driver for us to grow. This skill is what we are looking for in employees. " - WS, President, July 2019

From the results of the interviews, results, we found that from the C-level, Indonesian digital start-ups admit that innovativeness is a driver for the company's growth and having competitive advantages. Thus, this soft skill is a priority all people in digital start-ups must have.

"I usually deal with how to fulfil projects from users, offering great innovation that user needs are a plus." - EM, Content Analyst, April 2019 
"I challenge myself and my team members to have innovation, particularly in the innovation process to deliver education materials effectively." - SY, Tutor Manager, June 2019

"Even though I am in a non-operation division, innovativeness is very essential in my work, at least modifying my working process to be more effective and efficient." - AW, Technical Talent Acquisition, August 2019

We also found from the interview results that employees from all levels - staff level, supervisor, manager, senior manager and C-level - all shared that working at digital start-ups requires innovativeness skills. The innovations they mentioned not only gave birth to ideas that make products or services that can meet the needs and desires of the community, but also include innovating in everyday work to be more effective and efficient, such as shared by technical talent acquisition at the financial technology startup mentioned above.

\section{(7) Social interaction skills}

This soft skill, which shows an individual's ability to have effective communication and interaction in his/her community, was mentioned by three of ten respondents at this research. From the interview results, we learned a lower-level management representative, an HR generalist at the financial technology start-up, admitted that a novice worker at digital start-up must be able to bring him/herself.

\footnotetext{
"Besides having initiative and leadership skills, I think we should be active and confident working at a digital start-up”- OL, HR Generalist, August 2019
}

We analyse that good communication and coordination in formal and informal contexts are also important in one team and across teams.

"I usually work not only with my team but also across teams and with agents, partners and customers as well, so ability to communicate and social interaction skills str a must..." - NS, Virtual Product Development Manager, May 2019

Vol. 28, No. 3 December 2020 (C) Centre for Indonesian Accounting and Management Research Postgraduate Program, Brawijaya University 
"I see that many potential employees still have a lack of confidence, so they should boost their self-confidence level, and they will become greater..." - AZ, Chief Executive Officer, July 2019

From the interview results, we found that many employees of digital start-ups have an outstanding hard skill in fulfilling their tasks, but they also face a lack of selfconfidence. These phenomena were explored by the founder of a digital marketplace (Indonesian unicorn) and become constructive opportunities for academicians, schools and universities to provide suitable syllabus and learning models to meet this skill need.

(8) Initiative mindset

Two of the ten respondents acknowledge that having a mindset to take action without their superior's instruction is an important skill needed at digital start-ups.

\footnotetext{
"Initiative is very pivotal, because initiative comes from employees and leaders. When employees have initiative. and leaders drive them...much more ideas will emerge, and this is creating innovation for this company" - LT, Product Category Senior Manager, March 2019

"I encourage myself and my team to have initiative mindsets because fresh ideas come from initiative..." - ACA, Social Media Manager, June 2019
}

We found that an initiative mindset is an asset and becomes an innovation driver for all employee levels because, from this soft skill, more fresh ideas will develop that could be commercialised by the company if feasible.

\section{CONCLUSIONS}

In summary, to answer the research question about what are skills needed to manage disruptive digital business in Indonesia context, this research presents evidence that there are eight skills needed to manage a disruptive digital business in Indonesia. They require both soft skills, which consist of innovativeness, leadership, social Vol. 28, No. 3 December 2020 (C) Centre for Indonesian Accounting and Management Research Postgraduate Program, Brawijaya University 
interaction, initiative mindset, self-disruption, and critical thinking, and 2) hard skills, which consist of management skills and analytical thinking. This result was supported and relevant to previous study regarding skills needed in the future, which are information brokerage skills, basic ICT skills and management skills as part of the hard skills set, and social interaction, thinking skills and applications of knowledge as a soft skills set (Colombo et al.,2019).

From the results, we also found that soft skills sets are more needed in digital start-ups, where, based on the results of coding and themes, we found that innovativeness is the priority and was widely reported by six of the ten respondents. In the MerriamWebster Dictionary, the word "innovativeness" is defined as the quality of being innovative. We conclude from the interview transcripts that innovativeness skill is an employee's ability to be innovative in their jobs. This is not only about creating a new product or service; it also includes innovation for work process to be more effective and efficient. This result also supported and related to Ortiz-Villajos and Sotoca (2017), which acknowledges that there is a positive and significant relationship between innovation and business survival. Furthermore, we found in Indonesian disruptive digital business that innovation is not only vital for business survival, but innovativeness becomes a significant driver for the growth of digital start-ups, as stated by one respondent (president of the education technology start-up).

Leadership skill is second in the priority skills that referred by respondents. We conclude that leadership skill is the ability to lead oneself to achieve better job performance and to lead and help other employees achieve goals. This result supported 
and is relevant to previous research that leadership skill is one of the essential skills needed to manage a digital business (Sousa and Rocha, 2017).

We found that social interaction skill with all stakeholders is the third soft skill as referenced by three of ten respondents. We conclude that social interaction skills have a pivotal role in building and maintaining the digital start-up ecosystem in today's sharing economy. Botsman and Roger (2011) acknowledge that a sharing economy has the potential to strengthen social cohesion by connecting each individual through digital technology and stimulate entrepreneurship. Moreover, because the nature of a digital start-up involves remote work, social interaction is also done with the help of digital technology. Therefore, the ability to use digital communication platforms efficiently and effectively is important to all levels of employees (Kim and Song, 2018).

This research is novel because it is intended to complement the previous research of skills required at work, particularly what skills are needed in the disruptive digital era, especially in the Indonesian context. We found that there are three top soft skills sets that are needed to manage in disruptive digital business in Indonesia: (1) innovativeness, (2) leadership and (3) social interaction. We also found specific skills named "selfdisruptive" skills. Because digital start-up includes a mindset of survival and entrepreneurism, having self-disruptive mindset is an advantage for business growth. We conclude that a self-disruptive mindset and an execution to do something better and bravery to change oneself to be a better person are vital in this context.

Finally, we acknowledge that this preliminary result needs to be followed up with further research. Thus, we suggest future research could expand research object to another region of Indonesia regarding holistic results and add focus group discussion to 
collect primary data. Future research could also examine the effectiveness of selfdisruptive skills to accelerate digital start-up innovation.

\section{The Authors}

${ }^{1}$ Dewi Wahyu Handayani is a full-time doctoral student at School of Business and Management - Bandung Institute of Technology, Bandung Indonesia. Her main research are human capital management and learning organization.

Address: J1. Ganesha 10, Bandung - West Java, Indonesia, mobile phone: +6208159271326. For author designates to whom decision, proofs, and reprint requests should be sent, please contact Dewi Wahyu Handayani at email address: dewi_wahyu@sbm-itb.ac.id

${ }^{2}$ Jann Hidajat Tjakraatmadja is a professor of Knowledge Management and Learning Organization at School of Business and Management - Bandung Institute of Technology, Bandung Indonesia. He has been proactive in the professional academic community, and has been appointed President of Knowledge Management Society Indonesia (KMSI) since 2007. His main research is knowledge management, learning organization, innovation, intellectual capital, and human capital management. Address: Jl. Ganesha 10, Bandung - West Java, Indonesia, phone: +62-022-2500935, email: jannhidajat@ sbmitb.ac.id

${ }^{3}$ Achmad Ghazali is an assistant professor, lecturer and Director of Quality \& Assurance and Accreditation at School of Business and Management - Bandung Institute of Technology. His main research is knowledge management, human capital and learning 
102 Exploring Skills Needed for Disruptive .... .

organization. Address: Jl. Ganesha 10, Bandung - West Java, Indonesia, phone: +62-0222500935, email: achmadghazali@sbm-itb.ac.id 


\section{REFERENCES}

Bennet, N. and Lemoine, G. J. 2014. What a difference a word makes: understanding threats to performance in VUCA world. Business Horizons, (2014) Vol. 57, 311-317

Blank, S. 2010, "What's a startup? First principles", available at: http://steveblank.com/2010/01/25/ whats-a-startup-first-principles/ (accessed December 15, 2018).

Botsman, R. and Roger, R. 2011. What's Mine Is Yours: How Collaborative Consumption is Changing the Way We Live. HarperCollins Business.

Brian, L.D. and Barry, J.S. How to Be an Effective Trainer: Skills for Managers and New Trainers. 3rd Edition. Wiley Publisher (February 18, 1998)

Chard,K., Caton, S., Rana, O., and Burbendorfer, K., 2010. Social Cloud: Cloud Computing in Social Networks. IEEE Explore Digital Library. 2010

Christensen, C.M. 1997. The innovators' dilemma: when new technologies caused great firms to fail. Harvard Business Review Press.

Colombo, E., Mercorio, F., and Mezzanzanica, M., 2019. AI Meets Labor Market: Exploring the Link Between Automation and Skills. Elsevier, Vol.47(C) 2019: 27-37. DOI: $10.1016 /$ j.infoecopol.2019.05.003

Cusumano, M. A. 2015. How Traditional Firms Must Compete in the Sharing Economy. Communications of the ACM. January 2015, Vol.58, No. 1, P. 32-34. https://doi.org/10.1145/2688487

Creswell, J. W. 2013. Qualitative Inquiry and Research Design; Choosing Among Five Approaches. Sage Publication, Third Edition.

Guinard, D., Trifa, V., Matern, F., and Wilde, E., 2011. From the Internet of Things to The Web of Things: Resources-Oriented Architecture and Best Practices. Springer, New York, Dordrecht, Heidelberg, London, 2011 (Chapter 5).

Hamari, J., Sjoklint, M, and Ukkonen, A. 2015. The sharing economy: Why people participate in collaborative consumption. Journal of the Association for Information Science and Technology. Vol. 67 (9): 2047-2059. https://doi.org/10.1002/asi.23552

Hendarman, A.F., and Tjakraatmadja, J.H. 2012. Relationship among Soft Skills, Hard Skills, and Innovativeness of Knowledge Workers in the Knowledge Economy Era. Procedia - Social and Behavioral Science 52: $35-44$. DOI: 10.1016/j.sbspro.2012.09.439

Huusko, Liisa. 2006. The Lack of Skills: An Obstacle in Teamwork. Team Performance Management, Vo. 12 (1/2):5-16. 2006. https://doi.org/10.1108/13527590610652756

Vol. 28, No. 3 December 2020 
Kim, M. and Song, D. 2018. When Brand-Related UGC Induces Effectiveness on Social Media: The Role of Content Sponsorship and Content Type. International Journal of Advertising, Vol.37 (1): 105-24. https://doi.org/10.1080/02650487.2017.1349031

King, E. and Badham, R. 2018. Leadership in Uncertainty: The Mindfulness Solution. Organizational Dynamic (2018) Published online before print September. DOI: 10.1016/j.orgdyn.2018.08.005

Kun, P. and Weinberger, C. 2005. Leadership Skills and Wages. Journal of Labor $\begin{array}{lllll}\text { Economics. } & 2005 & \text { Vol. } & 23 & \text { (3): }\end{array}$ https://econpapers.repec.org/RePEc:iza:izadps:dp482

Lansiti, M., and Levien, R., 2004. Strategy as Ecology. Harvard Business Review. (March) 2004: 68-78.

Laar, E.V., Deursen, A.J.A.M., Dijk, J.A.G.M, and Haan, J. 2020. Measuring the levels of 21st-century digital skills among professionals working within the creative industries: A performance-based approach. Poetics. Elsevier. Available online 28 January 2020, 101434. https://doi.org/10.1016/j.poetic.2020.101434

Lawler, E. and Ledford, G. 1992. A skill-based approach to human resource management. European Management Journal. Elsevier. Vol. 10 issue 4: 383-391. https://doi.org/10.1016/0263-2373(92)90002-L

MIKTI, Indonesia Digital Creative Industry Society. 2018. Mapping \& Database Startup Indonesia 2018. MIKTI dan Teknopreneur Indonesia

Monoarfa.

2018

available

at

https://ekonomi.kompas.com/read/2018/12/03/175532426/peluang-kesuksesan-startup-

hanya-5-persen-apa-sebabnya (accessed February 12, 2019).

Nanda, R., and Rhodes-Kropf, M. 2013. Investment Cycle and Startup Innovation. Journal of Financial Economics. Emerald, Vol. 110. Issue 2. 2013: 403-418. DOI: 10.1016/j.jfineco.2013.07.001

Newing, H.S., Puri, R.K. and Watson, C.W. 2011. Conducting research in conservation: Social science methods and practice. Publisher: Routledge

Ngang, T.K. and Chan, N.A.A. 2015. Teacher Leadership and Classroom Management Practice on Special Education with Learning Disability. Procedia - Social and $\begin{array}{lllll}\text { Behavioural } & \text { Science. } & \text { Elsevier. } & \text { 20l. }\end{array}$ https://www.sciencedirect.com/science/journal/18770428

Nyhan, B. 1998. Strategy - Experiences of European Companies. Industrial and Commercial Training. Emerald. Vol. 30 No. 7, pp. 267273. https://doi.org/10.1108/00197859810242897

Reeves and Love. 2012. Developing Leaders in a VUCA Environment. Executive Development at UNC Kenan-Flagler. 2012

Vol. 28, No. 3 December 2020

(C) Centre for Indonesian Accounting and Management Research

Postgraduate Program, Brawijaya University 
Ortiz-Villajos, J.M. and Sotoca, S. 2018. Innovation and Business Survival: A Long-term Approach. Research Policy. Elsevier. Vol. 47(8): 1418-1436. https://ideas.repec.org/a/eee/respol/v47y2018i8p1418-1436.html

Rainsbury, E., Hodges, D.L., Burchell, N. and Lay, M.C. 2002. Ranking workplace competencies: Student and graduate perceptions. Asia-Pacific Journal of Cooperative Education, Vol. 3(2), 8-18. https://hdl.handle.net/10289/3219

Remane, G., Hanelt, A., Nickerson, R. C., and Kolbe, L. 2017. Discovering Digital Business Models in Traditional Industries. Journal of Business Strategy. Vol. 38 No.2: 41-51 2017. https://doi.org/10.1108/JBS-10-2016-0127

Ries, E. 2011. The lean startups: how today's the lean startup: how today's entrepreneurs use continuous innovation to create radically successful business, Crown Business. United States 2011

Rogers, E.M. 2003. Diffusion of Innovation. Free Press, New York

Rudiantara.

2019.

Available

at

https://www.kominfo.go.id/content/detail/7689/kemkominfo-bersama-kibar-luncurkangerakan-nasional-1000-startup-digital/0/berita_satker (accessed July 09, 2019).

Sale, J.E.M., Lohfeld, L.H., Brazil, K. 2002. Revisiting the Quantitative-Qualitative Debate: Implications for Mixed-Methods Research. Kluwer Academic Publisher, 2002 Nederland.

Saunders, M., Lewis, P. and Thornhill, A. 2016. Research Methods for Business Students., Seven Edition, Prentice Hall 2016

Scallmo, D., Williams, C.A. and Boardman, L. 2017. Digital transformation of business models - best practice, enablers, and roadmap. International Journal of Innovation Management. Vol.21. No.8. 1740014. https://doi.org/10.1142/S136391961740014X

Schuelke-Leech, B. 2017. A model for understanding the orders of magnitude of disruptive technologies. Technological Forecasting and Social Changes, Elsevier Vol.129 (C): 261-274. DOI: 10.1016/j.techfore.2017.09.033

Schumpeter, J.A. 1934, The Theory of Economic Development: An Inquiry into Profits, Capital, Credit, Interest, and the Business Cycle, Harvard University Press, Cambridge, MA

Sousa, M.J., and Rocha, A. 2017. Skills for Disruptive Digital Business. Journal of Business Research 2017.Emerald, Vol.94: 257-263. DOI: 10.1016/j.jbusres.2017.12.051

Tarde, G. 1969. The Law of Imitation. University of Chicago Press, Chicago

Vol. 28, No. 3 December 2020

(C) Centre for Indonesian Accounting and Management Research Postgraduate Program, Brawijaya University 
Vasconcelos, J. B., Kimble, C., Carreteiro, P., and Rocha, A. 2017. The Application of Knowledge Management to Software Evolution. International Journal of Innovation Management, Elsevier. Vol. 5. 2017. https://doi.org/10.1016/j.ijinfomgt.2016.05.005

Thompson, S. A., and Miller, K. 2018. Disruptive Trends in Higher Education. Journal of Professional Nursing. Elsevier. Vol.34 .2018: 92-96. https://doi.org/10.1016/j.profnurs.2017.11.008

Varian, H. R. 1999. Market Structure in the Network Age. Understanding the Digital Economy, MIT Press, 1999

Vargo,S. L., and Lusch, R. F. 2008. From Goods to Service(s): Divergences and Convergences of Logics. Industrial Marketing Management. 2008

Veit, D., Clemons, E., Benlian, A., Buxmann. A., Hess, T., Spann, M., Kundisch, D., Leimester, J.M and Loos, P. 2014. Business Models: An Information Systems Research Agenda. Business \& Information System Engineering. - Research Notes, Ausgabe/Number: 1, Erscheinungsjahr/Year: 2014. Seiten/Pages: 45-53.

Viska.2019. "Gerakan Nasional 1000 Startup" available at https://www.kominfo.go.id/content/detail/7689/kemkominfo-bersama-kibar-luncurkangerakan-nasional-1000-startup-digital/0/berita_satker (accessed August 19, 2019).

Xu, Y., and Koivumaki, T. 2018. Digital Business Effectuation: An Agile Approach. Computer in Human Behavior, Vol. 95: 307-314. https://doi.org/10.1016/j.chb.2018.10.021

Zaky, A. 2019. "Sharing Knowledge: A New Business Model \& Values of Network Strategy”. Knowledge Café, SBM-ITB, July 2019

World Bank Institute. 2008. "Measuring Knowledge in the World Economies: Knowledge Assessment Methodology and Knowledge Economy Index”, 2008 


\section{APPENDICES}

\section{Appendix 1. Relevant questions from semi-structure interview:}

Q1. Respondents profiles, such as; name, age, how long been working, job position, job description, does have subordinates or not?

Q2. “Could you share your experiences about skill used to support daily's work and to achieve your job performance?".

Q3. "Could you share your experiences about the challenges you face while working at digital startups?".

Q4. "How about your comment and suggestion regarding skills that needed in digital startups?”.

Q5. "Is there any innovation that you create?" if "yes" answer, "How about the process to create your innovation?", "What skills you needed to create innovation in your work?".

\section{Appendix 2. Semi-structure Interview Transcripts}

\section{Respondent 1}

Name of Interviewer: Dewi Wahyu Handayani (DWH); Name of Interviewee: LT (25 years old) - Male; Job Position: Product Category Senior Manager - (1 years); Type of Company: Digital Marketplace (Indonesian Unicorn); Company's Age: 10 years ; Time and Place: Thursday, March 21 ${ }^{\text {st }} 2019$, at 8:00 pm - 8:47 pm, telephone interview

LT : yang paling saya suka dan saya lihat kalau di digital e-commerce ini itu suka ide.....start with people, lalu cari orang yang pas, cari trial ide-ide. Kalau untuk ide dan eksekusinya ada matrix nya, matrix success lalu kita desain, kita hitunghitung potential impact by matrix, trus do feasibility. Trus... yang paling utama itu kalau buat ide baru itu ada impact dan possible. Penting juga untuk punya skill untuk melakukan inovasi....

LT : Kalau inovasi ada beberapa, saat ini ada inovasi yang saya pegang tapi ga bisa saya sebutkan karena masih confidential. Yang kita lakukan dalam inovasi itu adalah riset, developed feature baru......

LT : Sudah pasti sich prosentasinya lebih banyak bekerja dengan tim, dan bukan hanya bekerja dengan satu tim dibawah saya, tapi juga dengan lintas tim.

Vol. 28, No. 3 December 2020

(C) Centre for Indonesian Accounting and Management Research Postgraduate Program, Brawijaya University 
DWH : Saudara memiliki saran untuk perusahaan ini agar skills Saudara dapat meningkat dalam menunjang pekerjaan?

LT : Di digital marketplace ini ada learning class nya untuk yang mau belajar programming, kelas bahasa Inggris, Strategic Training, Leardership Training gitu....Kalau saya prinsipnya "learning as I go", saya suka banget dengan pekerjaan saat ini yang by project. Untuk saat ini saya mau belajar bahasa Mandarin karena kepake banget dalam pekerjaan saya.

DWH : Menurut Saudara perlukan inisiatif dalam pekerjaan saat ini?

LT : Perlu banget, karena inisiatif datang dari karyawan dan leader, dan menurut saya inisiatif yang timbul dan dimiliki oleh karyawan-karyawan disini sudah mereka miliki dari awal direkrut, memang memilih orang-orang yang tepat. Lalu, makin di drive sama leader-nya, beliau sangat terbuka sama inisiatif dan ide dari semua karyawan.

\section{Respondent 2}

Name of Interviewer: Dewi Wahyu Handayani (DWH); Name of Interviewee: EM (25 years old) - Male; Job Position: Content Analyst - (2 years); Type of Company: Education Technology Startup (Indonesian Centaur); Company's Age: 5 years; Time and Place: Thursday, April 12 $2^{\text {th }} 2019$, at 11:48am - 1:05 pm, face to face interview

EM : Saya saat ini sebagai Content Analyst, khususnya saya menangani Content Analyst untuk adults learning dan punya 2 anak buah, bekerja sudah dari akhir 2017 sampai dengan sekarang, saat ini saya sedang mengerjakan proyek $e$ learning nya PT Pertamina, jadi saya bersama tim tugasnya membuat konten, semua bentuknya video, e-learning.....dan itu...ehhhh...di...user nya adalah Pertamina.

EM : ee...saya masuk dari setengah 9 sampai dengan jam 17:30, kalau di tempat kerja saya ini kebanyakan adalah anak-anak muda.

DWH : Baik, untuk tim nya sendiri kalau Content Analyst di Education Technology startup ada berapa ya?

LT : Kalau untuk timnya sendiri ada 50 orang, semua nya masih muda-muda semua hehehehe (tertawa).....kalau staf saya ada 2 orang alumni UMN, dan tugasnya adalah membuat konten-konten pembelajaran, kita punya studio green screen juga buat studing video e-learningnya.

\section{Respondent 3}

Name of Interviewer: Dewi Wahyu Handayani (DWH); Name of Interviewee: NS (28 years old) - Female; Job Position: Virtual Product Development Manager - 3 years; Type of Company: Digital Marketplace (Indonesian Unicorn); Company's Age: 9 years ; Time and Place: Friday, May $3^{\text {rd }} 2019$, at 2:00 pm - 2:19 pm, telephone interview 
NS : Head saya mau buat inisiatif baru tentang Kemitraan *********....

NS : Maaf bu...he eh,,,,jadi sekarang saya pegang.....hmmm Februari kemaren saya jadi....emmm....Manajer Virtual Product.....

NS : jadi....kalau virtual product ini gampangnya kalo ibu beli pulsa di tempat saya...itu saya yang pegang.....pegang harganya gitu....

\section{Respondent 4}

Name of Interviewer: Dewi Wahyu Handayani (DWH);Name of Interviewee: SY (26 - 29 years old) - Male; Job Position: Tutor Manager - 2 years;Type of Company: Educational Technology Startup; Company's Age: 12 years ;Time and Place: Friday, June 28th 2019, by email interview

SY : Iya. Saat ini terdapat 18 orang tutor dibawah saya.

SY : Dalam posisi saat ini, dibutuhkan pembelajaran dalam critical thinking, analytical thinking, dan scientific reasoning. Selain itu juga training untuk berperan sebagai $H R D$ karena hal tersebut juga dibutuhkan untuk managing resource tutor.

SY : Iya, tim kerja per mata pelajaran. Pernah terlibat pekerjaan dalam lintas tim dalam proyek seperti Try-Out.

DWH : Adakah inovasi yang Saudara hasilkan dalam pekerjaan?

SY : Secara garis besar belum ada inovasi yang dihasilkan. Namun, dalam proses inovasi untuk efektifitas penyampaian materi pendidikan.

\section{Respondent 5}

Name of Interviewer: Dewi Wahyu Handayani (DWH);Name of Interviewee: ACA (25 29 years old) - Male; Job Position: Social Media Manager (Part of Content Team) - 2 years; Type of Company: Educational Technology Startup; Company's Age: 12 years ; Time and Place: Thursday, June $27^{\text {th }} 2019$, by email interview

ACA : Iya. Bawahan ada 1 orang.

ACA : Sebagai Social Media Manager dalam EdTech, hal -hal yang diperlukan dan dikuasai meliputi basic skills atau pengetahuan-pengetahuan dasar dalam berpikir (meliputi bahasa, logika, aritmatika, dll), general knowledge (meliputi pengetahuan-pengetahuan umum terhadap berbagai ilmu pengetahuan), serta pengetahuan dasar marketing dan penulisan yang berguna untuk menyampaikan ide-ide dan konten yang dimiliki.

ACA : Iya tim kerja. Pernah terlibat di pekerjaan lintas tim.

\section{$\underline{\text { Respondent } 6}$}

Vol. 28, No. 3 December 2020

(C) Centre for Indonesian Accounting and Management Research Postgraduate Program, Brawijaya University 
Name of Interviewer: Dewi Wahyu Handayani (DWH); Name of Interviewee: IPH (27 32 years old) - Male; .Job Position: Vice President of Engineering - 2,5 years; Type of Company: Educational Technology Startup; Company's Age: 12 years ; Time and Place: Friday, June $28^{\text {th }} 2019$, by email interview

IPH : Ya, anak buah langsung terdapat 14 orang di divisi IT.

IPH : Mendesain podcast atau blinkist tentang Management dan Leadership.

IPH : Iya, saat ini IT hanya 1 divisi, banyak project yang dikerjakan IT berhubungan dengan divisi lain seperti Marketing, Tutor, CS, dll. Kami memperlakukan divisi lain sebagai users atau stakeholders dari program kami.

DWH : Adakah inovasi yang Saudara hasilkan dalam pekerjaan?

IPH : Ya, inovasi dalam divisi IT ada 2 menurut saya, inovasi metodologi kerja dan dalam bentuk produk.

\section{Respondent 7 - Triangulation}

Name of Interviewee: AZ (36 years old) - Male; Job Position: Chief Executive Officer 9 years; Type of Company: Digital Marketplace (Indonesian Unicorn); Company's Age: 9 years ; Time and Place: Saturday, July $27^{\text {th }} 2019$, by sharing knowledge and $Q \& A$ session

AZ : Skills yang dibutuhkan adalah lebih ke confident yah....eee......kita butuh orang-orang yang disruptive artinya bisa berpikiran terbuka pada hal-hal baru, bisa menciptakan ide....saya kebetulan suka sama mahasiswa yang rebel...hehehhe...karena biasanya orang kayak gini open minded.....kalau saya suka sich yang kayak gitu....dia ga suka sama kondisi yang nyaman gitu.......kayak dia akan mikir sendiri saat ini kondisi nya ada yang salah ga ya....trus di disrupt lagi......kita suka ngadain hacketon....dan yang suka ngehasilin ide itu yang kayak gitu...saya aja kalau di kantor saya mengencourage teman-teman buat bisa melakukan self- disruption artinya keluar dari zona nyaman harus cari ide-ide baru

\section{Respondent 8}

Name of Interviwer: Dewi Wahyu Handayani (DWH); Name of Interviewee: OL (24 years old) - Female; Job Position: HR Generalist - 1,5 years; Type of Company: Financial Technology Startup; Company's Age: 4 years ;Time and Place: Saturday, August $24^{\text {th }}$ 2019, by telephone interview

OL :Skills yang dibutuhin ya Bu....hmmm...kalo di startup harus tahan banting nomor $1 \mathrm{Bu}$....karna bakal jadi kayak gurita....semua pekerjaan harus bisa....bahkan kadang kali startup pun punya sister company....dan mau ga mau kita pun handle itu....dan harus bisa improve kerjaan terus.......karna ekspektasi founder pasti bakal tinggi $\mathrm{Bu} . .$.

Vol. 28, No. 3 December 2020

(C) Centre for Indonesian Accounting and Management Research

Postgraduate Program, Brawijaya University 
OL : Iyah $\mathrm{Bu}$, walopun saya disini as HR Generalists, kadang kita dituntut untuk ngerjain hal lain...kayak GA (padahal ada Team nya sendiri), as SosMed (padahal ada Teamnya sendiri juga)....bahkan di HR pun kita se-team ada 9 orang (tapi waktu itu kita dituntut untuk harus tahu kerjaan recruitment level supervisor ke atas, operation dan internal event, dll) dan ini berlaku untuk 2 company, karna aku handle dua-duanya...

DWH : Bisa Saudara ceritakan tentang inovasi dari karyawan?

OL : Ngasi ide, inovasi, ini perlu banget Bu....karna startup ini kayak memang banyak banget yang harus diperbaikin...dan pengalaman aku saat itu, kita memang dituntut untuk kasi ide, tapi ini suka ter-pending karena adanya 3 founders (kalo yang 1 bilang OK, yang 2 bilang NO, ini gak akan jalan....jadi harus bikin ke-3 nya bisa OK)

DWH : Apakah kondisi ini membuat Saudara stres?

OL : Stres....ada Bu....ini pasti ada kadang kala......karna di startup itu mereka ga lihat prosesnya........mereka cenderung result oriented......ketika ga sesuai, mereka marah-marah uda biasa, nuntut lebih dengan deadline yang cepet itu udah biasa...Lalu, waktu ada audit ISO, dan aku sama sekali ga pernah handle ini...........dan banyak dokumen yang dibutuhin (dan sebelumnya ga pernah ada), jadi mau ga mau harus bikin dari awal, dengan deadline yang deket......dan ga ada 1 pun HR yang bantu, dan aku juga yang harus di audit....di saat inilah yang bikin stress

DWH : Dari pengalaman Saudara, sebagai karyawan milenial, tantangan terbesar kerja di startup apa?

OL : Harus punya jiwa leader $\mathrm{Bu}$, karena jangan jadi leader, kita di startup harus punya mindset "act like an owner", jadi kita kerja bagaikan kerja untuk company sendiri.....lalu interaksi yang diperluin itu communication nomor $1 \mathrm{Bu}$....karna kalau ada misscom, ini lebih berabe lagi, dan harus tahu bagiannya masingmasing.....ga ada yang namanya "diajarin" harus bisa "lari" sendiri....selama di startup, semua berlomba-lomba untuk menonjol Bu... karna kita report langsung ke founder, jadi berlomba-lomba menonjol (tapi ga sikut2an juga ya $\mathrm{Bu} \odot$ )

\section{Respondent 9}

Name of Participants: Dewi Wahyu Handayani (DWH); Name of Interviewee: AW (25 years old) - Male; Job Position: Technical Talent Acquisition - 1,2 years; Type of Company: Financial Technology Startup; Company's Age: 4 years ; Time and Place: Sunday, August $25^{\text {th }} 2019$, by telephone interview

DWH : Menurut Saudara skills yang dibutuhkan apa saja untuk kerja di startup?

AW : Skills yang dibutuhkan sebenernya basic sich $\mathrm{Bu}, 1)$ Harus mengerti proses End-to-End interview sampai orang itu onboard di kantor pada saat hari pertama,

2) Mengerti tentang technology yang sedang happening sekarang, 3) Negosiasi,

Vol. 28, No. 3 December 2020

(C) Centre for Indonesian Accounting and Management Research Postgraduate Program, Brawijaya University 
112 Exploring Skills Needed for Disruptive .... .

4) Tahu cara menggali pengalaman orang dan harus kurang lebih bisa baca personality orang gimana. 